\title{
Infância YouTuber: problematizando representações de crianças inseridas na cultura de sucesso
}

\section{YouTuberchildhood: questioning representations of children in the culture of success}

\section{Infancia YouTuber: problematizando representaciones de niños insertados en la cultura del éxito}

\author{
Darcyane Rodrigues de Melo $^{1}$ \\ Bianca Salazar Guizzo ${ }^{1}$
}

DOI: http://dx.doi.org/10.20435/serie-estudos.v24i50.1162

\begin{abstract}
Resumo: O artigo tem como propósito principal problematizar as representações infantis postas em circulação a partir de vídeos postados em canais do YouTube e protagonizados por três youtubers mirins que estiveram, ao longo dos anos de 2017 e 2018, no ranking de mais acessados, com grande índice de visualizações e inscritos. Para empreender as análises, foram selecionados 27 vídeos publicados entre janeiro de 2014 e dezembro de 2017, a partir dos quais foram analisadas as imagens e as falas das crianças youtubers, bem como foram discutidos alguns comentários postados por seus seguidores. A partir do campo teórico dos Estudos Culturais em Educação, de viés pós-estruturalista, as análises centraram-se na discussão do modo como as crianças youtubers propagam e reforçam representações em decorrência das quais podem ser produzidas identidades infantis voltadas à cultura de sucesso, a qualcompreende tanto o status de ser uma criança famosa, considerada uma celebridade, quanto a posição de uma criança empreendedora, que, com o seu próprio ganho financeiro, consegue adquirir bens de consumo e investir na sua carreira de youtuber.
\end{abstract}

Palavras-chave: infância; YouTube; Estudos Culturais.

Abstract: The main purpose of the article is to question the representations of children put into circulation through YouTube videos and led by three YouTubers who throughout 2017 and 2018 have been in the most-viewed ranking, with a high number of views and subscribers. 27 videos posted between January 2014 and December 2017 were chosen for analysis, through which the images and the speeches of YouTuber children were analyzed, and some comments posted by their followers were discussed. Based on the theoretical field of Cultural Studies in Education and with a post-structuralist bias, the analyses focused on the discussion of how YouTuber children propagate and reinforce representations as an outcome of which children's identities aimed at

\footnotetext{
${ }^{1}$ Universidade Luterana do Brasil (ULBRA), Canoas, Rio Grande do Sul, Brasil.
} 
the culture of success can be produced. Since the culture of success comprises both the status of being a famous child, considered a celebrity, and the position of an entrepreneurial child who earns their own financial resources, and manages to acquire consumer goods and invest in their YouTube career.

Keywords: childhood; YouTube; Cultural Studies.

Resumen: El artículo tiene como propósito principal problematizar las representaciones infantiles puestas en circulación a partir de vídeos publicados en canales de YouTube y protagonizados por três pequenos youtubers que en los años de 2017 y 2018 estuvieron en la clasificación de más accedidos, con un gran índice de visualizaciones e inscripciones. Para empreender los análisis se seleccionaron 27 vídeos publicados entre enero de 2014 y diciembre de 2017, a partir de los cuales se analizaron las imágenes y las palabras de los niños youtubers, así como se discutieron algunos comentarios publicados por sus seguidores. A partir del campo teórico de los Estudios Culturales en Educación, de tendência pos estructuralista, los análisis se centraron en la discusión del modo como los niños youtubers propagan y refuerzan representaciones a consecuencia de las cuales se pueden producir identidades infantiles inmersas en la cultura del éxito. Siendo así que la cultura de éxito comprende tanto el estatus de ser un niño famoso, considerado una celebridad, como la posición de un niño emprendedor, que con su propia ganancia financiera logra adquirir bienes de consumo e invertir en su carrera YouTuber.

Palabras clave: infancia; YouTube; Estudios Culturales.

\section{INTRODUÇÃO}

O presente artigo está inserido no campo teórico dos Estudos Culturais em Educação, de viés pós-estruturalista, e tem como foco a discussão sobre os modos como as crianças estão vivendo suas infâncias e constituindo-se como sujeitos de um determinado espaço e de um determinado tempo. Para realizar essa discussão, foram escolhidos três canais do YouTube, apresentados por crianças que utilizam essa ferramenta tecnológica para postar vídeos e, de certo modo, propagar representações e ensinamentos a outras crianças. Ressalta-se que tanto as crianças que produzem os vídeos, quanto as que a estes assistem, já nasceram inseridas nos meios tecnológicos de informação e de comunicação, sendo - ambos - sujeitos de uma cultura participativa (JENKINS, 2009). Quando se sinaliza que representações são propagadas através dos vídeos postados no canal do YouTube, infere-se que estas acabam ensinando e educando os sujeitos que as produzem e os que a elas assistem. Sendo assim, os canais do YouTube analisados foram tomados como artefatos culturais que propagam pedagogias culturais, proporcionando aprendizagens que são colocadas em circulação e que reverberam na constituição de identidades dasinfâncias contemporâneas. 
Referimo-nos a infâncias, no plural, na medida em que desnaturalizamos as concepções de infância e a entendemos através de sua história, passando a identificar não só um tipo de infância, mas sim diversas infâncias que, para serem significadas, dependem dos contextos em que as crianças que as vivenciam estão inseridas (DALBERGH;MOSS; PENCE, 2003; BUJES; DORNELLES, 2012; GUIZZO;BECK; FELIPE, 2013).

As infâncias do mundo ocidental têm passado por algumas transformações ao longo dos anos.A representação de infância característica do século XIX foi fabricada e caracterizada pela ingenuidade, dependência dos adultos, imaturidade e necessidade de proteção, indicando fronteiras bem demarcadas entre adultos e crianças (ARIÈS, 2016; VEIGA, 2004). Nessa perspectiva, a identidade era tomada como única, centrada, coerente e estável. Contudo, em meados do século XX, as transformações sociais e culturais contemporâneas abalaram essa construção, e novas formas de viver a infância configuraram-se, principalmente relacionadas aos avanços tecnológicos, indicando identidades múltiplas, fragmentadas, efêmeras e móveis, as quais perduram na contemporaneidade, mostrando-nos crianças independentes em determinados aspectos, desconcertantes, acostumadas com a instabilidade, com a incerteza e com a insegurança. As crianças do mundo ocidental do século XXI vivem em meio ao espetáculo, ao imediatismo, à visibilidade, ao protagonismo e ao consumo(COSTA, 2009). É notável que as crianças ganharam uma centralidade, tornando-se participantes ativas em suas culturas, sobretudo em espaços como o YouTube, por meio do qual são ensinados modos de ser criança na contemporaneidade. Nessa direção, o principal objetivo deste artigo é problematizar e analisar as representações de infâncias colocadas em circulação por youtubers infantis, especialmente aquelas que se vinculam ao que chamamos de cultura do sucesso.

Para dar conta desse objetivo, o artigo está estruturado da seguinte forma: 1) discutimos o modo como entendemos os conceitos que dão sustentação teórica ao artigo, quais sejam: cultura participativa erepresentação; 2) situamos o leitor sobre o campo em que desenvolvemos a pesquisa: o YouTube, bem como descrevemos os canais analisados; 3 ) apresentamos os resultados analíticos na seção "Celebridades infantis: representações de crianças na cultura de sucesso"; 4) traçamos algumas considerações finais. 


\section{CULTURA PARTICIPATIVA E REPRESENTAÇÃO COMO FERRAMENTAS ANALÍTICAS}

Jenkins (2009) é uma das principais referências para dar sustentação às discussões que propomos neste artigo. Segundo ele, plataformas como o YouTube proporcionam o que conceitua como cultura participativa, pois através dela é possível desenvolver, interagir e aprender. Sites como o YouTube combinam produções de mídia e distribuição com recursos de redes sociais, tornando-se um lugar ideal para criar, conectar, colaborar e circular na/com a mídia (CHAU, 2010). Nesse sentido é importante considerarmos a afirmação de Jenkins (2009, p. 47) quando diz que "Se o trabalho de consumidores de mídia já foi silencioso e invisível, os novos consumidores são agora barulhentos e públicos". Sujeitos comuns tornam-se participantes e se manifestam a partir do YouTube, que vem sendo considerado um poderoso canal de distribuição para a produção cultural amadora.

Jenkins (2009) afirma ainda que o YouTube pode ser considerado a primeira plataforma a direcionar tanta atenção ao papel das pessoas comuns na mídia, com faixas etárias diversas. Notam-se, por exemplo, crianças ensinando outras crianças sobre o que elas precisam saber para se tornarem participantes plenas da sua cultura. O YouTube, cada vez mais, se confirma como um artefato cultural produtivo que provoca mudanças nos hábitos das pessoas e consequentemente altera a cultura em que elas estão inseridas.

De modo sucinto, é possível afirmar que a cultura participativa refere-se à forma como a sociedade contemporânea (em função da popularização da Internet) tem se distanciado da condição de receptora passiva. Atrela-se ainda à produção de conhecimento e disseminação de informações e ideias. Segundo Jenkins (2009), o caráter interativo da internet proporciona a cultura participativa e, consequentemente, produz mudanças no modo como os sujeitos, incluindo as crianças, relacionam-se com os meios de comunicação que propagam e reforçam representações que reverberam nas suas constituições identitárias.

Nos Estudos Culturais, para Hall (2016), a representação é entendida como um sistema de signos e é expressa por meio de pintura, de fotografia, de filme, de um texto, de uma expressão oral. Ainda nessa perspectiva, o conceito de representação incorpora todas as características de indeterminação, ambiguidade 
e instabilidade atribuídas à linguagem (SILVA, 2014).A constituição das identidadesdos sujeitos é dependente da representação, é por meio da representação que nossas identidades adquirem sentido. Segundo Woodward (2014, p. 18),

[...] a representação inclui as práticas de significação e os sistemas simbólicos por meio dos quais os significados são produzidos, posicionando-nos como sujeito. É por meio dos significados produzidos pelas representações que damos sentido à nossa experiência e àquilo que somos.

Assim, representar significa utilizar a linguagem para expressar algo sobre o mundo ou representá-lo a outras pessoas. Representar envolve o uso da linguagem, de signos, de imagens. Por fim, é possível afirmar que a representação é o modo como os diferentes grupos sociais e/ou culturais são apresentados nas mais diferentes formas de inscrição cultural, como nos discursos e nas imagens. No caso dos canais do YouTube analisados neste artigo, cabe afirmar que os vídeos produzidos pelos youtubers mirins produzem e reforçam determinadas representações cujos efeitos são visíveis na constituição identitária de sujeitos infantis contemporâneos.

\section{YOUTUBE: ARTEFATO CULTURAL QUE ENSINA}

Se é o conceito de "cultura" que permite equiparar a educação a outras instâncias culturais, é o conceito de "pedagogia" que permite que se realize a operação inversa. Tal como a educação, as outras instâncias culturais também são pedagógicas, também ensinam alguma coisa. (SILVA, 2010, p. 139).

A epígrafe que introduz esta seção sinaliza que o YouTube é uma dessas "outras instâncias" que podem ser acionadas como uma pedagogia cultural que dissemina representações e ensinamentos aos sujeitos que o acessam. Silva (2010) salienta que está ocorrendo um apagamento das fronteiras entre instituições educacionais e as outras esferas, principalmente por causa das alterações nos sistemas de informação e comunicação. A internet é considerada uma das responsáveis pelas mudanças que torna difícil o discernimento entre o conhecimento adquirido no dia a dia, o conhecimento da cultura de massa e o conhecimento escolar, sendo todas essas formas de conhecimento entendidas como pedagogias culturais, importantes para a constituição identitária dos sujeitos, não devendo, portanto, ser ignoradas. 
O YouTube é uma plataforma de mídia que interage com outras mídias e permite que as pessoas possam criar e postar vídeos e circular os seus conteúdos. Os criadores de conteúdo que utilizam o YouTube são chamados de youtubers. Neste artigo, é realizada uma análise cultural a partir de vídeos de três canais protagonizados por crianças, duas meninas e um menino, que vêm mobilizando milhares de outras crianças (suas seguidoras) na web. Os canais foram nominados como: canal A, canal B e canal C (Quadros 1, 2 e 3). Nos quadros a seguir, serão apresentadas características das crianças protagonistas, bem como dos seus próprios canais ${ }^{2}$.

\section{Quadro 1-Canal A}

Algumas informações sobre a Youtuber: a menina que protagoniza o canal A tem 12 anos, é branca, de classe média e mora com os pais. É natural de São José dos Campos, SP, porém, quando iniciou a gravar vídeos, estava residindo em Itajubá, MG. Após tornar-se Youtuber famosa, mudou-se novamente para a cidade natal. Em seu canal, informações atuais relatam que a Youtuber está residindo no Canadá.

Como o canal surgiu:começou a gravar vídeos aos seis anos de idade, cujos conteúdos retratavam cenas cotidianas e brincadeiras preferidas. Os primeiros vídeos foram gravados e postados no YouTube com o intuito de fazer com que seu pai, que morava na França, pudesse acompanhar seu desenvolvimento. Como os vídeos eram públicos, a menina começou a conquistar outro público que não fazia parte de sua família e, em 2012, já tinha mais de 100 mil inscritos em seu canal.

Ano de início do canal: 06/08/2007

Ano considerado para pesquisa: de 2012 a 2017

Número de inscritos: 2.868 .687

Número de visualizações: 713.162 .326

Número de vídeos publicados: 1376

Temáticas das postagens: DIY e receitas; LOL; Halloween; Novelas, historinhas e séries; Review e games; Bonecas: Baby Alive, Reborn, etc; Tags e desafios; Vlogs de viagens e passeios; Diário do intercâmbio; React; Material escolar; Presentes e cartinhas; Maquiagens e looks; Músicas, efeitos e musical.ly; Pizza na manteiga; Monster High e Ever After High; História da sereia; Comerciais e Furby.

Fonte: as autoras.

${ }^{2}$ As informações apresentadas sobre os Canais A, B e C foram obtidas em novembro de 2017. 
Quadro 2 - Canal B

Algumas informações sobre a youtuber: a menina do canal B aparece nos vídeos, algumas vezes sozinha e em outros momentos em parceria com sua mãe e sua irmã menor. Reside no Rio de Janeiro, onde nasceu e mora com seus pais e a irmã caçula. É branca, tem 10 anos de idade e, desde os seis anos, faz vídeos para o seu canal.

Como o canal surgiu:a menina passou a conquistar o público desde que era modelo dos tutoriais feitos pela mãe no canal em que ensinava penteados para meninas. Contudo era seu desejo ter o próprio canal para compartilhar o dia a dia, suas brincadeiras e atividades preferidas com outras crianças. Seus vídeos rapidamente ganharam um número significativo de seguidores.

Ano de início do canal: 10 de agosto de 2013

Ano considerado para pesquisa: de 2013 a 2017

Número de inscritos: 4.512 .505

Número de visualizações: 1.733 .464 .816

Número de vídeos publicados: 1385

Temáticas das postagens: Fran para meninas; Nina para meninas; Halloween; Eu sou rica ou pobre?; O namorado da mãe; Desafios; Perguntas idiotas; A pestinha; Troca de papéis; Tipos; Pokemon Go; Amoeba e massinha; Coisas que acontecem na escola; O ataque da gosma; Músicas infantis com animações super; A maldição da bruxa; A boneca vingativa; A boneca que criou a vida; Ciúmes; Bullying com aluna nova; Vale a pena ver de novo; Aniversário da Nina; Teatrinhos, Baby Alive; A bebê abandonada; Fama a qualquer preço; Amor ou dinheiro? A mãe fútil filha carente; Micos e pegadinhas; Praia e piscina; Maquiagem; Disney; Penteados para menina

Fonte: as autoras. 
Algumas informações sobre o youtuber: a criança que protagoniza os vídeos do Canal C é um menino de 8 anos, nascido na Vila Canária em Salvador, na Bahia. Mudou-se para o Rio de Janeiro para investir na carreira de youtuber e ator. Sua mãe abriu mão da faculdade e do trabalho em nome da carreira do filho, principalmente para acompanhá-lo nas viagens, eventos e participações em programas (DIÓGENES, 2016 ).

Como o canal surgiu: em entrevista para o jornal Correio, em 17 de maio de 2016, a mãe do menino conta para a jornalista Thais Borges que seu interesse por postar vídeos surgiu através da influência do tio, que já fazia gravações para a plataforma Vine, um aplicativo para postagens de vídeos curtos. O primeiro vídeo do menino, gravado pelo tio e postado no Vine, obteve um número de visualizações surpreendente e, por esta razão, o tio seguiu fazendo vídeos do menino, porém as postagens passaram a ser inseridas na plataforma YouTube, onde despontou.

Ano de início do canal: 24/10/ 2014

Ano considerado para pesquisa: de 2014 a 2017

Número de inscritos: 4.4999 .305

Número de visualizações: 330.125 .083

Número de vídeos publicados: 162

Temáticas das postagens: Paródias; Rico vs pobre; desafios; tag e fatos da escola.

Fonte: as autoras.

Os canais A, B e C somaram um total de 2923 vídeos, dos quais 27 foram considerados para análise neste artigo. Os títulos dos vídeos e o número de visualizações auxiliaram no momento da seleção, além disso buscamos privilegiar a análise daqueles que, de alguma forma, acionavam representações de crianças empreendedoras e inseridas na cultura de sucesso. Os vídeos selecionados dos canais A, B e C foram assistidos em ordem cronológica, dos mais antigos para os mais recentes, a fim de voltar o olhar para os movimentos e as mudanças que os vídeos e os criadores de conteúdo apresentavam. As imagens de maior relevância, considerando repetições e recorrências, foram cruciais para o desenvolvimento da problematização que ora propomos. Destacamos que, embora os vídeos escolhidos para análise sejam públicos, eles foram produzidos para outro fim (que não o de pesquisa) e, por uma questão ética, optamos por preservar os rostos das crianças youtubers, assim como seus nomes. 


\section{CELEBRIDADES INFANTIS:REPRESENTAÇÕES DE CRIANÇAS NA CULTURA DE SUCESSO}

Momo e Costa (2010) já diziam que as subjetividades e as identidades infantis na pós-modernidade têm sido produzidas e constituídas por um cenário de espetáculo, visibilidade e efemeridade. Neste aspecto, as crianças youtubers estão contribuindo para formações de identidades com esses perfis.

Os vídeos analisados neste artigo são protagonizados por três crianças que, na atualidade, possuem status de crianças famosas e de sucesso, cuja visibilidade deve-se a seus vídeos, os quais atingem milhões de pessoas, principalmente o público infantil.

Os dados sobre número de vídeos e número de inscritos são métricas que o próprio YouTube cria para acompanhar a performance de seus usuários. Inclusive, é o YouTube que estimula que seus usuários façam vídeos cada vez melhores e recebam benefícios correspondentes com o número de inscritos em seus canais. A premiação mais comemorada entre os youtubers é a placa de ouro, enviada pelo próprio YouTube quando um canal atinge um milhão de inscritos e a qual é denominada pelo site como "Uma celebração de sucesso". Os protagonistas dos três canais aqui analisados já receberam a placa de ouro.

As crianças dos canais A, B e C publicaram vídeos para comunicarem o recebimento da placa, bem como postaram comentários a respeito disso, os quais são reproduzidos abaixo:

A minha placa de 1 milhão finalmente chegou. Fiquei muito feliz e emocionada e divido esse momento com vocês. MUITO OBRIGADA POR TUDO. Espero que gostem do vídeo.Clique em gostei e se inscreva no canal, que ficarei muito feliz! (Canal A). ${ }^{3}$

Essa placa não é só minha é de todos nós porque sem vocês nada disso teria acontecido. Muito obrigada por me assistir, pela confiança e principalmente por todo esse amor. Isso não se compra se conquista! Amo vocês e vou sempre fazer meus vídeos para tentar alegrar, ajudar mesmo que seja um pouquinho e todos nós juntos por um mundo mais feliz e com mais amor! (Canal B). ${ }^{4}$

\footnotetext{
${ }^{3}$ As citações decorrentes do material empírico ora analisado estão em itálico, com o intuito de diferenciá-las das citações teóricas utilizadas. Disponível em: https://www.youtube.com/ watch?v=9INAeugM5Rw.Acesso em: 19 out. 2017.

${ }^{4}$ Todos os trechos transcritos a partir dos vídeos analisados ou dos comentários decorrentes deles foram aqui reproduzidos do modo como foram publicados na plataforma YouTube, ou seja, sem
} 
Nesses dois comentários, é possível perceber que as youtubers sugerem que o "sucesso" também é daqueles que se inscrevem em seus canais, bem como daqueles que assistem aos seus vídeos e comentam-nos. De certo modo, isso acaba sendo um modo estratégico para manter seus seguidores fiéis uma vez que os posicionam como parte do sucesso obtido.

Junto com a placa de ouro, o YouTube envia uma carta ao youtuber que alcançou um milhão de seguidores. Em vídeo postado no Canal C, o tio do menino youtuber lê a carta que inicia com a seguinte frase: "Você é maior que Vancouver. É maior que Veneza. Você é até maior que Las Vegas" (Canal C) $)^{5}$.

Através de estratégias como o envio da placa de ouro e da carta que a acompanha, o YouTube reforça posições de sucesso entre os criadores de conteúdo e incentiva-os a cada vez mais "medir seu sucesso" através de classificações de acordo com o número de inscritos em seus canais. No site do YouTube há uma seção intitulada "níveis de benefícios" em que há o seguinte texto:

Temos orgulho dos nossos criadores de conteúdo: Nos empenhamos para reconhecer o esforço e a dedicação de criadores de conteúdo como você. Oferecemos apoio e incentivo por meio de benefícios e oportunidades feitas sob medida para o nível específico do seu canal. ${ }^{6}$

A partir daqui, procuramos apresentar e discutir os modos como essa perspectiva de sucesso foi sendo construída entre as crianças dos canais $A, B$, e C. Ao assistir aos primeiros vídeos desses canais, não foram encontrados indicativos de que as crianças protagonistas dos vídeos, ainda tão pequenas, já almejassem o sucesso da forma que o YouTube reforça na sua página na internet. Então, para compreender como essas crianças chegaram a números consideráveis de seguidores e, consequentemente, como se tornaram crianças de sucesso, optamos por assistir aos vídeos dos canais A, B e C, a partir do primeiro vídeo postado de cada um deles.

O que é notável, principalmente nos vídeos dos canais A e B, é que eles foram gravados de forma mais despretensiosa, permitindo alguns erros de gravações, uma qualidade de imagem inferior, num clima de proximidade com as câmeras,

correção ortográfica, linguística e/ou gramatical. Disponível em: https://www.youtube.com/ watch?v=8zKIvY3PBGY. Acesso em: 13 set. 2017.

${ }^{5}$ Disponível em: https://www.youtube.com/watch?v=XY12vcZE39k. Acesso em: 23 out. 2017.

${ }^{6}$ Disponível em: https://www.youtube.com/intl/pt-BR/yt/creators/awards. Acesso em: 20 fev. 2018. 
como se aquele que estava assistindo do outro lado do vídeo fosse alguém bem próximo das youtubers e vice-versa. As intenções iniciais eram a de mostrar seus quartos, suas coleções de brinquedos e suas respectivas funcionalidades, além dos momentos de brincadeiras.

O primeiro vídeo postado pela criadora de conteúdo do Canal B é ilustrado com um cenário simples, com a qualidade de imagem meio turva, com alguns "erros de gravação" não editados. O conteúdo do vídeo ocupa-se em mostrar bonecas, roupas no roupeiro, acessórios como cortinas, o ventilador de teto cor de rosa, bem como a televisão branca com imagens de princesa. Além disso, o próprio modo como a menina vestia-se não era revestido de produção alguma, tal como é visto nos vídeos mais recentes em que se percebe que ela está bem penteada e maquiada, bem como vestida com roupas e acessórios que levam a marca de seus patrocinadores.

No seu primeiro vídeo, assim que a menina começa a falar e a mostrar os brinquedos do quarto, evidencia-se a troca do R pelo L em sua fala: "Essa tartaruga foi a que eu ganhei ela lá na Disney, foi o meu 'plimeiro blinquedo' que eu comprei lá. O nome dela é 'Blilhante', é uma tartaruga muito boazinha", o que demonstra que a criança ainda estava em processo de desenvolvimento da fala, mas mesmo pequena já exercia o papel de criança protagonista.

A fala de encerramento dos primeiros vídeos ainda não traz pedidos para que os espectadores sigam-na ou se inscrevam em seu canal, sendo, portanto, uma despedida simples, com apenas um "tchau, tchau": "Então é isso, então tchau, tchau, nos outros vídeos eu mostro as minhas Baby Alive, as bonecas. Hoje só foi o quarto mesmo, então tchau tchau, até os próximos vídeos".

Porém, na medida em que as postagens aumentavam, ao longo de cada ano, foi perceptível que os vídeos se tornavam cada vez mais elaborados, mais bem produzidos e, sobretudo, que as crianças protagonistas desses vídeos tornavam-se cada vez mais desenvoltas, demonstrando uma intimidade crescente com as câmeras. Além disso, em decorrência de já estarem fazendo parte da cultura do sucesso incentivada pelo próprio YouTube, ao final de cada vídeo postado, as crianças protagonistas dos canais incentivavam seus espectadores a participarem: fazendo sua inscrição no canal, publicando comentários e/ou atribuindo like (gostei) ao vídeo. Em decorrência dos primeiros vídeos que se tornaram sucesso de maneira despretensiosa, percebe-se, nos vídeos posteriores, uma preocupação em 
elaborá-los cada vez mais para que, assim, se mantivessem no ápice do sucesso, o qual requeria a participação efetiva de seus seguidores.

Em abril do ano de 2015, após dois anos em que os primeiros vídeos do canal B foram postados na internet, um trailer do referido canal (Canal B ${ }^{7}$ ), chama a atenção pela sua trilha sonora, pelas chamadas/vinhetas das seções em que o canal se divide, indicando uma produção mais rebuscada e que tem por objetivo divulgar o canal através dos conteúdos nele abordados como: desafios muito engraçados; minhas aventuras de viagens; review de brinquedos; receitas deliciosas, vlog comprinhas; aventura e alegria.

Os desdobramentos que o trailer do vídeo produziu podem ser evidenciados através de comentários a seguir,publicados por seguidores do canal.

Comentário 1: [...] eu te amo meu sonho é encontrar com você ou ir a um encontrinho seu [...] mas eu moro em Maceió Alagoas e é muito longe do Rio de Janeiro e a minha mãe não tem condições de ir para o Rio de Janeiro. [...] te amooooo eu queria muito te ver, te amo muito pois.

Comentário 2: [...] sou uma menina ok tenho 10 anos mas posto vídeo do celular do meu vô! meu nome é Ana Paula e vc ganhou mais uma inscrita manda Beijo num vídeo pra mim!!!

Comentário 3: [...] quando eu edito meus vídeos no Imovie a tela fica em um quadrado e a tela fica preta! Me explica como o vídeo fica inteiro assim como o seu? $\left(\right.$ Canal B ${ }^{8}$.

Os comentários indicam que, nessa dinâmica do sucesso e do consumo, não necessariamente bens materiais são os mais desejados. As crianças também consomem exemplos que acreditam que devam ser seguidos, consomem ídolos, estilos de vida e consomem técnicas, dicas que possam auxiliá-las a se tornarem um youtuber de sucesso. É possível afirmar que o Youtube contribui para dar novos significados à infância, uma infância conectada às novas mídias e ao mundo, uma infância cuja tendência é voltar-se para o lado profissional, uma infância que interage com crianças de diversas partes. Bujes (2001) defende que a representação de infância não é fixa e pode se alterar conforme o contexto em que as crianças estão inseridas. Já Narodowski (2013) argumenta que, para falar sobre infância, deve-se revisar o contexto mundial em que se desenvolvem, principalmente quando sofre influência das tecnologias.

\footnotetext{
${ }^{7}$ Disponível em: https://www.youtube.com/watch?v=JfgHHZ6u1ZM. Acesso em: 24 jun. 2017.

${ }^{8}$ Disponível em: https://www.youtube.com/watch?v=JfgHHZ6u1ZM. Acesso em: 24 jun. 2017.
} 
O sucesso de um youtuber está relacionado, em grande parte, à contabilização do número de inscritos que o canal possui. Quanto mais inscritos, mais atrativo o canal se torna, não só para os espectadores, mas também para anunciantes de produtos e de marcas que estabelecem parcerias com esses canais de maior sucesso para exibir suas marcas e propagandear seus produtos.

Quando o YouTube começa a remunerar os criadores de conteúdo, é perceptível que investimentos são feitos para melhorias do canal. Com equipamentos mais avançados, cenários atraentes e boa qualidade dos vídeos, os canais tendem a se tornar mais encantadores e a conquistar ainda mais inscritos.

Em vista disso, famílias e responsáveis investem nas crianças, estipulando dias de gravações, auxiliando na produção dos vídeos e colocando-os no ar.O que se observa, portanto, é que algo que inicialmente revestia-se de caráter lúdico, passa - com o aumento de seguidores e, consequentemente, do sucesso - a ter um caráter empreendedor e profissional. A fala da youtuber do canal A e de seu pai vai na direção do que estamos argumentando:

Youtuber: Eu comecei mais como brincadeira, mas depois eu achei tão legal que eu quis trabalhar mesmo com isso, eu acho que hoje é a minha vida, porque eu amo trabalhar com isso.

Pai da Youtuber: A preocupação é pela segurança, então a mãe e ela filtram as mensagens, entre ela e os fãs dela, então trabalham as duas juntas, $e$ a gente não deixa a [...] dar nenhuma informação adicional de onde mora exatamente, o endereço, etc. (Canal $\left.A^{9}\right)$.

Outra consequência do sucesso é que os youtubers de maior destaque começam a transitar em outras mídias, tornando-se notícias em jornais e participando de programas de TV. Uma matéria de um programa dominical da TV aberta brasileira dedicou-se a discutir sobre adolescentes e crianças que são sucesso na internet. Dentre os youtubers citados na matéria, estava uma das meninas cujo canal analisamos neste artigo. Sobre ela a repórter afirma que bastou a postagem de um vídeo em que chamava seus seguidores para um encontro que uma multidão de meninas apareceu para vê-la e, mais do que isso, tentar tirar uma foto junto a ela. Durante a reportagem, a youtuber afirma que adora ser reconhecida porque é divertido e que gosta muito de dar autógrafo e tirar foto. Na reportagem, questionamentos sobre a questão financeira foram feitos. Ao que sua mãe

\footnotetext{
${ }^{9}$ Disponível em: https://www.youtube.com/watch?v=bSsjHQUOXfo. Acesso em: 8 dez. 2017.
} 
respondeu: "O sucesso dela tem um retorno financeiro [...] daria para a gente se sustentar muito bem. Mas não é o caso, porque ele é todo guardado na poupança [...] para ela usar [...] quando ela tiver idade para administrar tudo isso"10.

Os temas abordados pelo programa validam posições ocupadas por alguns youtubers, quais sejam: ter sucesso e ser empreendedor. O sucesso, que pode ser medido pelo número de inscritos no canal, também pode ser evidenciado fora dos vídeos, assim como nos "encontrinhos" presenciais e diante de aparições em outras mídias.

Pensando a criança em meio a essas transformações tecnológicas, Narodowski (2013) ressalta que a criança que está em meio à tecnologia, utilizando-se dela, recebe um lugar de reconhecimento, diferente das suas participações e posições na escola e na família. Através da tecnologia, as crianças têm maior reconhecimento, sendo que a interação entre elas e as ferramentas tecnológicas garante uma participação privilegiada. Neste artigo, ao se considerarem as posições do autor supracitado, pode-se afirmar que as crianças youtubers aqui analisadas representam uma infância hiper-realizada, caracterizada por seus contatos constantes com Smartphones, Tablets, Smart TVs e que já não se imaginam sem internet.

As relações a partir da internet ultrapassam os espaços virtuais e podem chegar até mesmo a encontros presenciais. O encontro com os youtubers ocorre em espaços públicos como shoppings e livrarias, estando muitas vezes relacionados ao lançamento de um livro ou de um produto que leve o seu nome, assim como tendo relação com a divulgação de alguma marca.

Os youtubers dos canais $\mathrm{A}$, B e C mobilizam grande número de crianças e fãs que se emocionam, gritam, choram com a presença deles em encontros presenciais. É difícil mensurar emoções, mas é possível dizer que, ao ver os vídeos desses encontros, as emoções das crianças que participam dos "encontrinhos" com seus "ídolos" youtubers se assemelham às de quando um fã encontra um artista famoso, oriundos do cinema ou da televisão. Constata-se também que, diante das novas mídias, surgem novos tipos de ídolos, neste caso, os youtubers mirins.

Um dos vídeos analisados mostra a youtuber do canal A em um encontro presencial, num shopping na cidade de São Paulo, cujo principal objetivo era o

10 Disponível em: http://g1.globo.com/fantastico/noticia/2015/09/adolescentes-e-criancas-sao-sucesso-na-internet-e-atraem-milhoes-de-fas.html. Acesso em: 12 jan. 2018. 
lançamento de sua coleção de roupas. Quando ela chegou próximo do público, os celulares ficaram a postos para fotos, e as mães e os responsáveis pelas crianças, assim como elas, queriam chegar perto dela, queriam tocá-la e, até mesmo, abraçá-la.

Outro vídeo, da youtuber do canal B, mostra a menina participando de uma sessão de autógrafos de um livro lançado por ela. Logo na chegada do local onde ocorreu a sessão de autógrafos, a youtuber é entrevistada por um repórter para um canal de TV aberta e, ao fundo, as crianças que estavam a sua espera começam a gritar seu nome. O título do vídeo chama a atenção para a quantidade de pessoas que queriam vê-la e ter o livro autografado por ela: "Mais de 5 mil pessoas do Brasil, Portugal, Espanha...", o que reforça a representação de crianças como celebridade e um desejo explícito de permanência desse status, observável quando a youtuber e sua família agradecem aos seus seguidores, dizendo: "Vamos continuar fazendo sempre mais e melhor para vocês"11.

O menino youtuber do Canal C, após lançar seu primeiro livro em 2016, trouxe até ele um público que, em busca de um autógrafo, fez uma fila enorme que deu voltas nos corredores de um shopping em Salvador (BORGES, 2016).

Outra forma de reforçar as representações de celebridades é quando marcas infantis (de brinquedos, de roupas, de sapatos, de alimentos, etc.) vão ao encontro dosyoutubers mirins, fazendo com que eles se tornem cada vez mais conhecidos. Nesse sentido, trata-se de uma via de mão dupla, em que a marca ganha visibilidade por estar sendo exposta para um público-alvo bastante específico que contempla pais, responsáveis e crianças e, em contrapartida, a criança youtuber ganha destaque por estar fazendo vídeos e propagandas de marcas infantis consagradas.

Um dos vídeos analisado intitula-se "Look perfeito para o verão", que mostra roupas e acessórios, além de apresentar detalhadamente uma sapatilha recém-lançada por uma famosa marca de sapatos infantis. Durante o vídeo, a youtuber do canal A fala:

Para montar os meus looks perfeitos para o verão a TRICAE ${ }^{12}$ me mandou essa sapatilha da PAMPILI'13, ela é muito fashion, ela é animal print e com-

\footnotetext{
${ }^{11}$ Disponível em: https://www.youtube.com/watch?v=pPsnE61i2to. Acesso em: 28 nov. 2018.

12 Loja virtual de diversos produtos destinados às crianças.

${ }^{13}$ Marca de sapatos infantis.
} 
bina com todas as minhas roupas, eu gostei muito dela porque ela tem essa estampa de oncinha, ela é dourada, tem esse lacinho e também eu gosto muito da PAMPILI porque os sapatos da PAMPILI são muito confortáveis e dá para correr e brincar bastante! (Canal A). ${ }^{14}$

Nesse caso, outra forma de remuneração é quando a imagem de um youtuber famoso torna-se alvo de interesse de determinadas marcas, podendo o criador de conteúdo em questão tornar-se garota/garoto propaganda. A imagem exposta em outdoors e em vitrines de grande circulação, como ocorre em lojas de shoppings, também reforça a representação das crianças youtubers ocupando o lugar de celebridades. Dito de outro modo, as discussões até aqui empreendidas reforçam as representações crianças em ascensão, de sucesso e percebidas aos olhos de outras crianças como celebridades. O sucesso está relacionado tanto ao reconhecimento, pelo aumento de inscritos em seus canais, o que faz ganhar notoriedade e cada vez mais visibilidade, quanto ao retorno financeiro, ou seja, o sucesso não se resume a "ser famosa", mas a ser alguém que já conquista/compra suas coisas com seu próprio esforço. Assim como Knupp (2015) identificou que concursos de beleza infantis funcionam como um negócio, uma forma de trabalho infantil informal, pode-se dizer o mesmo dos youtubers mirins, pois eles vão em busca de sucesso e acabam recebendo retorno financeiro em consequência disto.

Um vídeo do canal B que analisamos intitula-se "O primeiro iPhone do dinheiro do vídeo". Ele coloca em evidência a representação de criança que "trabalha" se divertindo e consegue adquirir objetos de consumo. No vídeo, ao mesmo tempo que a câmera foca no iPhone comprado, a menina exclama aos seus seguidores: "E eu que comprei meninas, com o dinheiro do vídeo, e olha lá, eu que comprei, não foi papai nem mamãe".

Após a circulação desse vídeo acima, os comentários vão desde curiosidades de outras crianças querendo saber como se ganha dinheiro com os vídeos até parabenizações pelo seu esforço e por começar cedo, como no excerto a seguir:

Comentário 1: [...] a garotinha conectada! Parabéns pelo seu iPhone, comece cedo assim, conquistando suas coisinhas com seu esforço! Você merece, você é muito fofa! Beijinhos para você [...], com gostinho de orgulho! (Canal B). ${ }^{15}$

\footnotetext{
${ }^{14}$ Disponível em: https://www.youtube.com/watch?v=4IUs_6nAHvs. Acesso em: 28 set. 2017.

${ }^{15}$ Disponível em: https://www.youtube.com/watch?v=AOnkyT4S5ik. Acesso em: 10 jan. 2018.
} 
A partir da opção metodológica adotada nesta pesquisa de assistir aos vídeos em ordem cronológica crescente, foi possível perceber que, a cada vídeo postado, o número de inscritos aumentava, transformando o que seria um simples vídeo sobre o dia a dia da criança em uma oportunidade de negócio, em um passo a mais para atingir e/ou permanecer na fama e ter sucesso (inclusive financeiro). As crianças, motivadas pelos likes e inscrições, por sua vez, vão aprimorando seus vídeos, cenários, equipamentos adquiridos, e elas mesmas passam a evoluir gradativamente em suas performances frente aos vídeos, adquirindo mais desenvoltura e desejos crescentes de visualização. Assim, esses desejos transformam-se em pedidos de likes e de inscrições por quem assiste aos seus canais, mormente porque as crianças sabem que, ao pedir likes, terão retornos, até mesmo financeiro, pois quanto mais vistos são, quanto mais seus canais recebem um "gostei", mais os vídeos recebem anúncios e são remunerados.

No que diz respeito aos anúncios e aos vídeos publicitários, esses são inseridos nos canais, principalmente no início dos vídeos, mas também podem aparecer quando os vídeos já estiverem em andamento, e são eles que representam parte do retorno financeiro dos youtubers. Desse modo, há grande probabilidade daquele que assiste ter as atenções voltadas para as campanhas publicitárias que entram em cena nesta etapa das postagens dos youtubers. Portanto destaca-se que os youtubers não possuem um salário direto através do site, mas este intermedeia os pagamentos para os youtubers conforme as publicidades que são postas em circulação, enquanto os vídeos estão sendo assistidos.

Assim, cada uma dessas ações vai tornando a criança empreendedora, de modo que os vídeos não podem mais ser considerados apenas diversão e lazer, pois eles têm outra conotação a partir do momento em que a remuneração entra em questão. Todavia, importa destacar que o empreendedorismo vai além da remuneração por anúncios e merchandising, na medida em que os youtubers passam a criar produtos com sua própria marca. Nesse sentido, questiona-se: o que os youtubers que compõem esta pesquisa têm em comum? Todos eles lançaram livros e fizeram eventos com sessões de autógrafos que mobilizaram muitas crianças para não só adquirirem o livro, mas também para abraçarem e estar perto deles, ou seja, trata-se de youtubers que se tornaram ídolos. 


\section{CONSIDERAÇÕES FINAIS}

Com base no que expusemos e discutimos ao longo do artigo, percebe-se que o YouTube, de certo modo, ensina as crianças a serem empreendedoras, a investirem nos seus canais através de criações de roteiros de vídeos, mudanças de cenários, frequências ao postar vídeos. Ademais, ensina as crianças a cultuarem o sucesso e a serem famosas, evidenciado pelos encontros com fãs e interações com eles, almejando sempre tê-los por perto, admirando e dando likes em suas produções.

Assim, a representação posta em evidência é a de uma criança empreendedora que não almeja, de modo algum, desocupar o lugar de fama ocupado e, por isso, empenha-se em manter seus seguidores fiéis aos conteúdos que publica. Pode-se afirmar que tal representação reverbera nas identidades das crianças que assistem ao que postam esses youtubers, pois desejam não só obter os produtos que propagandeiam, mas também comportar-se como eles e, até mesmo, tornarem-se um youtuber famoso como eles. Dito de outro modo: os youtubers infantis são formadores de opinião, uma vez que propagam representações sobre modos de ser e de se comportar, ensinam seus pares a serem de certos tipos, a desejarem determinados produtos e a comportarem-se de determinadas maneiras. Eles não são usuários passivos de plataformas (tal como o YouTube), mas são ícones que divulgam marcas e estilos de vida a serem seguidos.

Em tempos de cultura participativa, fluxo de conteúdos por múltiplas mídias, as crianças também acessam mídias e vão em busca dos entretenimentos que Ihes interessam e, assim, tornam-se participativas em suas culturas. Elas usam o YouTube para expor suas ideias e criar conteúdos. As crianças são participativas nas relações com as mídias, envolvem-se com elas, e utilizam-se das ferramentas atuais disponíveis (smartphones, tablets, Smart TVS). Na posição de youtubers que ocupam, expõem em público seus desejos, suas preferências por determinadas marcas, tornando-se sujeitos formadores de opinião. Com essas ferramentas em mãos, utilizam-nas para se comunicar e transmitir conteúdos para outras crianças. Em contrapartida, as crianças youtubers também tornam-se persuasivas, já que incitam as crianças espectadoras a participar de seus canais, com a promessa de disponibilização de materiais exclusivos, de participação em grandes desafios e em concursos. O YouTube dá voz às pessoas comuns, que mudam hábitos e consequentemente mudam a cultura onde estão inseridas (JENKINS, 2009). A interatividade entre as crianças se dá através de comentários, elas publicam, trocam 
informações, pedem a participação. Logo, as crianças não são passivas diante das mídias, não esperam por horários programados para assistir a um programa de TV, agora o que se vê é uma familiaridade com as novas mídias e interação entre espectadores e youtubers. Criam materiais que podem atrair seguidores, numa infância envolvida com a tecnologia, produzindo conteúdos que sustentam a finalidade de obter sucesso e renda.

\section{REFERÊNCIAS}

ARIÈS, Philippe. História social da criança e da família. 2. ed. Rio de Janeiro: LCT, 2016.

BORGES, Thais. Conheça Issac do Vine, o baiano de 7 anos que é um fenômeno na internet. 2016. Disponível em: http://www.correio24horas.com.br/noticia/nid/conheca-isaac-dovine-o-baiano-de-7-anos-que-e-um-fenomeno-na-internet/. Acesso em: 1ำ nov. 2017.

BUJES, Maria Isabel Edelweis. Infância e maquinaria. 2001. Tese (Doutorado em Educação) - Universidade Federal do Rio Grande do Sul (UFRGS), Porto Alegre, 2001.

BUJES, Maria Isabel; DORNELLES, Leni. Alguns modos de significar a infância. In: DORNELLES, Leni; BUJES, Maria Isabel (Org.). Educação e infância na era da informação. Porto Alegre: Mediação, 2012.

CHAU, Clement. YouTube as a participatory culture. New Directions for Youth Developmen, n. 128, p. 65-74, 2010. Disponível em: https://www.ncbi.nlm.nih.gov/pubmed/21240954. Acesso em: 22 jun. 2016.

MOMO, Mariangela; COSTA, Marisa Vorraber. Crianças escolares do século XXI: para se pensar uma infância pós-moderna. Cadernos de Pesquisa, São Paulo, v. 40, n. 141, p. 96591, set./dez. 2010.

COSTA, Marisa Vorraber. Educar-se na sociedade de consumidores. In: COSTA, Marisa Vorraber (Org.). A educação na cultura da mídia e do consumo. Rio de Janeiro: Lamparina, 2009.

DALBERGH, Gunilla; MOSS, Peter; PENCE, Alan. Qualidade na educação da primeira infância: perspectivas pós-modernas. Porto Alegre: Artmed, 2003.

DIÓGENES, Juliana. Baiano de 7 anos, Issac já tem empresário e muda para o Rio em nome da carreira. 2016. Disponível em: http://brasil.estadao.com.br/noticias/geral,baiano-de-7anos-isaac-ja-tem-empresario-e-se-muda-para-o-rio-em-nome-dacarreira, 10000081620. Acesso em: 12 dez. 2016.

GUIZZO, Bianca Salazar; BECK, Dinah Quesada; FELIPE, Jane. Infâncias, gênero e sexualidade: articulações possíveis. In: FELIPE, Jane; GUIZZO, Bianca Salazar; BECK, Dinah Quesada (Org.). 
Infâncias, gênero e sexualidade nas tramas da cultura e da educação. Canoas, RS: Editora da ULBRA, 2013.

HALL, Stuart. Cultura e representação. Rio de Janeiro: Ed. PUC-Rio/Apicuri, 2016.

JENKINS, Henry. Cultura da convergência. 2. ed. São Paulo: Aleph, 2009.

KNUPP, Antonio Jorge Ferreira. Escolas de pequenas misses: um estudo sobre os concursos infantis de beleza. 2015. Dissertação (Mestrado em Educação) - Universidade Luterana do Brasil (ULBRA), Canoas, RS, 2015.

NARODOWSKI, Mariano. Haciaun mundo sin adultos. Infancias híper y desrealizadas en la era de los derechos del niño. Actualidades Pedagógicas, n. 62, p. 15-36, jul./dez. 2013.

SILVA, Tomaz Tadeu da. A produção social da identidade e da diferença. In: SILVA, Tomaz Tadeu da (Org.). Identidade e diferença: a perspectiva dos Estudos Culturais. 15. ed. Petrópolis, RJ: Vozes, 2014.

SILVA, Tomaz Tadeu da. Documentos de identidade: uma introdução às teorias do currículo. 3. ed. Belo Horizonte: Autêntica, 2010.

VEIGA, Cynthia. Infância e modernidade: ações, saberes e sujeitos. In: FARIA FILHO, Luciano Mendes (Org.). A infância e sua educação: materiais, práticas e representações. Belo Horizonte, MG: Autêntica, 2004.

WOODWARD, Kathryn. Identidade e diferença: uma introdução teórica e conceitual. In: SILVA, Tomaz Tadeu da (Org.). Identidade e diferença: a perspectiva dos estudos culturais. 15. ed. Petrópolis, RJ: Vozes, 2014.

\section{Sobre as autoras:}

Darcyane Rodrigues de Melo: Mestre em Educação e graduada em Psicologia pela Universidade Luterana do Brasil (ULBRA).E-mail: darcyrmelo@hotmail.com

Bianca Salazar Guizzo: Doutora e mestre em Educação pela Universidade Federal do Rio Grande do Sul (UFRGS). Professora e pesquisadora do Curso de Pedagogia e do Programa de Pós-Graduação em Educação na Universidade Luterana do Brasil (ULBRA). Recentemente realizou estágio pós-doutoral na Universidade de Bolonha (Itália).E-mail: bguizzo_1@hotmail.com

\section{Recebido em junho de 2018}

\section{Aceito em novembro de 2018}

